\title{
Ligeti Dániel
}

\section{VÁLTOZATOK EGY ARCHETÍPUSRA - MARDUK ÉS NINURTA MEZOPOTÁMIAI ISTENEK ÖSSZEHASONLÍTÁSA}

\section{Absztrakt}

Kutatásomban a mezopotámiai panteon két jelentős istenének összehasonlítását végzem el, akik bizonyos irodalmi forrásokban meglepő átfedéseket mutatnak egymással. A tanulmány hipotézise, hogy meghatározott feltételek teljesülésével Marduk és Ninurta a panteon egy bizonyos pontjától számítva szinkretizmusba kerülhetett egymással. A szinkretizmust a két istenről alkotott elképzelés közös archetípusának körülhatárolásával támasztom alá, amelyet két mítosz elemzésével végzek el. Vizsgálatom során öt kritérium alapján hasonlítom össze a két istent, és a hasonlóságokat a közös archetípus meghatározásához használom fel. A vizsgálati szempontok a következők: körülmények, motivációk, konfliktusok, eszközök, jutalom. Az összehasonlításhoz feldolgozott és lefordított mitológiai szövegeket használok fel, a mítoszok narratív szerkezetét nagy egészként vizsgálom és kerülöm az sumer-akkád filológiai problémákat. A két isten összehasonlításával és archetípusuk meghatározásával egy olyan fenomenológiai és eszmetörténeti jelenség tárulhat elénk, amelyen keresztül árnyaltabb képet kaphatunk a mezopotámiai vallás isteneinek bonyolult felépítéseiről, azok uralkodói jelentőségéről, valamint az istenek megalkotása során az egyénben zajló szellemi mechanizmusokról. A szoros átfedéseket mutató mítoszok összehasonlításából született eredmény csak egy szeletét fedi le a két istenről alkotott elképzelésnek, így megfelelő alapot ad Marduk és Ninurta karaktereinek jövőbeni összehasonlító kutatásaihoz.

\section{Kulcsszavak: archetípus; Mezopotámia; mitológia}

\section{Bevezetés}

A mezopotámiai mitológiára részletgazdag kidolgozottsága ellenére többnyire a tagoltság jellemző. A kezdetben különálló, később az egységes szerveződésre törekedő városok sokáig saját hierarchiai szabályaik szerint értelmezték a panteonokat, ez később a magasabb fokú szerveződés során az uniformizálódáshoz vezetett. Az istenek közötti felismerhető átfedések mitikus történeteken és ikonográfiai ábrázolásokon keresztül maradtak ránk. Wilfred G. Lambert 1986-ban rámutatott, hogy szoros hasonlóságot tapasztalhatunk a mezopotámiai vallási irodalom két fontos szövege között: Marduk, babiloni főisten teremtéseposza, az Enuma elis, valamint az eredetileg termékenység és időjárás isten Ninurta, Anzu madárral folytatott küzdelmét leíró Anzu mítosz között.

Selena Wisnom egy 2019-es tanulmányában két motívum mentén hasonlította össze és támasztotta alá a két mítosz, Lambert által felvetett intertextualitását. Wisnom munkájában a narratív szerkezet és történeti elemek hasonlóságából adódóan a két mítosz egymásra történő hatását sem zárta ki: „A szövegekre történő keresztbeutalás az 
ókori világ nagy részén általános és jól bevált költői gyakorlat, mert korlátozottabb szövegsorozat létezett, amely az írástudóktól elvárható volt. [...] Az ékírásírás megtanulásának folyamata különféle irodalmi kompozíciók lemásolásával járt, amely során a tanulók megismerték az irodalmi klasszikusokat.” (Wisnom, 2019, p. 271.) Esetünkben éppen emiatt nem következtethetjük csupán a két szöveg hasonlóságából Marduk és Ninurta szinkretizmusát. A két isten teljeskörű szinkretizmusát még nem sikerült bizonyítani, melyet csupán két mü összehasonlításából nem is lehet. Ehhez a szöveges forrásokon kívül ismernünk kellene többek között a pontos kultikus gyakorlatokat, az istenek átfogó ikonográfiáját, a szimbólumok pontos jelentését, az isten hétköznapokon, ünnepnapokon vagy háborús időszakban betöltött pontos szerepét, a kultusszal kapcsolatos uralkodói intézkedéseket stb. Az így összegyűjtött információk megfelelő konstellációja végezetül a két isten között fennálló szinkretizmust bizonyíthatná, annak viszont a biztos kijelentéséhez mindenekelőtt birtokunkban kellene lennie, amihez a legkevesebb hozzáférésünk van: az egyén vallási élményéhez. Jelen tanulmány célja az Enuma elis és Anzu mítosz főszereplő istenei között tapasztalható hasonlóságok és különbségek elemzése. Az eredmény Marduk és Ninurta szinkretizmusának további kutatásához szolgálhat alátámasztásul, és a két isten archetípusának körvonalazását célozza, melynek meghatározásával a vallást gyakorló személy istenről alkotott elképzeléséhez, illetve az isten kultuszának megértéséhez kerülhetünk közelebb.

A vizsgálatban elsősorban az istenek attribútumainak és karaktereinek átfedését keresem a történetek szerkezetében és narratív felépítésében, azokat nagy egészként vizsgálva, kerülve a sumer-akkád filológiai és fordításbeli problémákat. A mítoszokat az eredeti sumer-akkád szakmai-filológiai és lábjegyzetelt angol fordításban elsődlegesen Stephanie Dalley: Myths from Mesopotamia (Dalley, 2008) című gyűjteményéből idézem és vizsgálom. Az idézett angol szövegrészletek magyarra történő fordítását az eredeti sémi nyelv ismeretének hiányában önállóan nem léptem meg. A szövegben történő tájékozódás kedvéért a magyar fordítást a Rákos Sándor által közölt és Komoróczy Géza által lektorált Gilgames/Agyagtáblák üzenete (Rákos, 1974) irodalmi-költői fordításából illesztem be. Dalley és Rákos szöveggyűjteménye nem fedi egymást minden ponton, amely elsősorban a két közlés közt eltelt több mint harminc évnek, és az ezalatt végbement újabb táblák fel- és újra feldolgozásának, valamint a fordítások átdolgozásának tudható be: A vizsgált Anzu mítoszból Rákos magyar fordításában csak a szöveg első táblájának egy töredéke került közlésre, és az Enuma elis sem mutat teljeskörű terjedelmi egyezést Dalley közlésével. Emiatt a mítoszoknak bizonyos hiányzó magyar fordításait nem tudtam pótolni és feltüntetni. Rákos munkáit Dalley fordításainak filológiai mivoltából és a két szöveggyűjtemény kiadása közt eltelt évek miatt nem használom elsődleges idézetekként. A mitológiai terminusokat Dalley könyvében olvasható írásmódnak megfelelően idézem és hivatkozom, a sorokat pedig a felhasznált szöveggyűjtemények tördelése alapján számozom. 
1. sz. kép: Pecséthenger, Kr. e. 9-7. század. Hosszú ruhás alak nyilakat lő egy kígyószerű teremtményre. Valószínűleg Marduk és Tiamat harca.

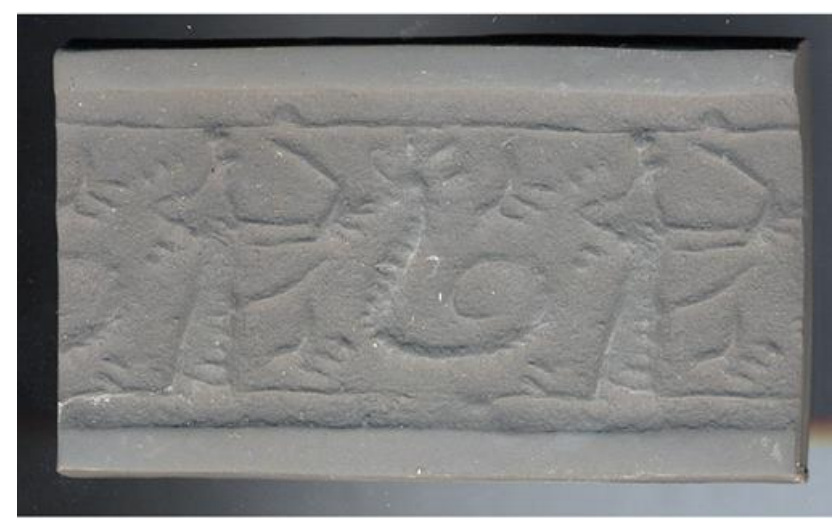

Forrás: British Museum online katalógus, Museum ID: 138129

Marduk és Ninurta elemzését a következő összehasonlítási szempontok mentén végzem el: 1. Körülmények, 2. Motivációk, 3. Konfliktusok, 4. Eszközök, 5. Jutalmak. A vizsgált kritériumok mindkét történetben azonosan jelen vannak, így, ha a két történet azonos sémára íródott, akkor az első megírása után a második történet kritériumait tudatosan szabhatták az isten karakteréhez. A vizsgálat elvégzésével a kapott eredmény olyan szimbólumok lefordításából tevődik össze, amelyek Marduk és Ninurta mítoszokban olvasható karaktereinek fenomenológiai magyarázatául szolgálhatnak, egy róluk alkotott mélyebb, kollektív szinteket meghaladó értelmezést remélve. Ezzel az ismerettel szilárdabb érvekre alapozhatjuk a kettejük között feltételezett szinkretizmust, valamint tisztább képet kaphatunk a szinkretizmus tágabb értelemben vett fogalmáról is.

\section{Fogalmi tisztázás}

Andrew A. George Marduk and the cult of the gods of Nippur at Babylon című 1997-es tanulmányában Marduk szobrok feliratait és régészeti adatait vizsgálta meg, amelyeket babiloni-, illetve nippuri központú istenek szentélyeiből tártak fel Babilonban (George, 1997). A hét vizsgált szoborból az első három a város központi vallási komplexumaiban, a negyedik, ötödik és hatodik külső vallási régiókból származik. Az utolsó három épület elsősorban nippuri bázisú istenek templomai, ezekben régészeti ásatások eredményei alapján Marduk foglalja el a központi helyet, így Ninurta szentélyében is, amely az istenre utaló nevet is viseli (E-hursag-tilla = Ház, Ami Elpusztítja A Hegyet). Andrew szerint ez a szobor az elhelyezéséből adódóan Marduk Ninurtával alkotott lokális szinkretizmusáról árulkodhat, amelyben a babiloni főisten nem helyettesítette, csak abszorbálta Ninurta jellemvonásait. Tehát helyi értelemben Ninurta csak egy változatává vált Marduknak. (George, 1997)

Az alátámasztani kívánt szinkretizmus vallástörténeti fogalma alatt a fuzionálással ellentétben nem a feltétlen teljeskörü összeolvadás értendő. Assmann meghatározása szerint szinkretizmus alatt egy olyan fajta megfeleltetést értünk, amelyben az ideák megférnek egymás mellett és a két fél találkozása szükségszerűen nem az egyik vagy másik megsemmisülését vonja maga után. A szinkretizmus feltétele legalább kettő, egy 
lokális és egy általános kultúrából származó entitás, amelyek találkozásakor az egyik fél teret enged a másik attribútumainak. Ezeknek az elemeknek az együttélése a későbbiekben egy olyan harmadik kulturális nyelv megjelenését eredményezi, amely létre sem jöhetett volna a felek egyesülése nélkül, valamint életben tartja az átvett ideákat. (Assmann, 1996) Esetünkben ennek a közös nyelvnek a részeit képezik azok a toposzok és motívumok, amelyeken a két vizsgált mítosz istene közösen osztozik.

Marduk és Ninurta a vizsgált mítoszokban kimutatható hasonlóságaik a két isten közös archetípusát sejtetik. Az archetípusok Carl Gustav Jung alkotta meghatározása alatt az emberi tudattalanban rögzült ősi képek sémáit értjük. Az archetípus kutatás egy olyan tudatalatti konstrukció létezését feltételezi, amelyben a kollektív fejlődésünk során összegyűjtött tapasztalatok és információk ősképek, illetve távoli emlékek formájában rögzülnek, ezek általában vallási, spirituális, művészi vagy más szellemi/spirituális tevékenység végzése során szimbólumokként törnek felszínre, metaforikus formában kifejezésre juttatva a lélek belső képeit. Ezek a kollektív információ hordozók (mítoszok, történetek, mesék stb.) figyelemre méltóan sokáig életben maradnak, sokszor egymásra építkeznek és lenyomataikként szolgálnak a közös belső térkép kifejezésének és változásának. Vallástörténeti meghatározásban a kollektív tudattalan a mítoszalkotás során képekké alakítja az archetípusokat, így mitologémákon (mitologikus motívumokon) keresztül szimbolikus nyelven juttatja kifejezésre őket. (Tokarev, 1988) Jung szerint a primitív embert az őt körülvevő környezet objektív leírása sosem érdekelte annyira, mint inkább a jelenségek (naplemente, holdfogyatkozás, villámcsapás stb.) belső történésként való megélése. Ezek mitizálása a lélek metaforikus kivetülései. (Jung, 2011)

Marduk első megjelenése kisebb rangú sumer istenségként a harmadik évezredre tehető. A panteonban elfoglalt státusza csak Hammurapi uralkodása (Kr.e. 1792-1750) alatt kezd fokozatosan felértékelődni, az óbabiloni időszak (Kr. e. 20. sz.-16. sz.) alatt kultusza csupán Babilon területére terjed ki. Marduk előléptetését a panteon csúcsára Hammurapi törvényeiből ismerjük, amely Babilon Mezopotámia feletti uralmát vagy legalábbis arra irányuló igényét tükrözi. Marduk kultuszának ezt a tendenciáját összeköthetjük egy babiloni identitás feltételezésével, amely hatással lehet az isten városi patrónus-, illetve főisteni szerepkörével. Azért, hogy Marduk először csak a Babilon városi, majd később a birodalmi főisteni posztot betölthesse, két feltételnek kellett teljesülnie: egyrészt Babilonnak szakítania kellett a nippuri hagyományos Enlil-központú panteon berendezkedéssel. Ennek pontos dátumát nem lehet meghatározni, mivel Marduk főisteni pozíciójáról szóló dokumentumok megjelenése előtt is feltételezhetjük, hogy ez a lokális főisteni gondolat már érvényben volt. Másrészről egy új, Babilon központú világmodellnek is meg kellett jelennie, amelyben a terjeszkedő birodalom a világgal azonosul, aminek központja (így a világ központja is egyben) Babilon (Abusch, 1999). Marduk kultuszának tetőzése az első évezred fordulójára tehető. Babilon Kr. e. 689-es asszír pusztítását követően az isten szobrát elhurcolják a városból, templomát és zikkuratát lerombolják, ezt Marduk népe romlottsága feletti haragjaként értelmezik. Az újbabiloni dinasztia (Kr.e. 9. sz. - 6. sz.) függetlenségét megünnepelve újjáépítteti Marduk templomát, Nabonidus király (Kr.e. 555-539) Kr.e. 555-ös uralma alatt Marduk helyére Sin kerül a város új patrónus istenének pozíciójára. Mardukot egészen a hellénizmusig 
tisztelik, arról azonban, hogy kultusza meddig marad életben, nincs információnk (Handy, 1992).

Ninurtát az asszír periódust megelőzően elsősorban mezőgazdasági és termékenységi istenként tisztelték. Ezt alátámaszthatja nevének jelentése „Föld-Úr”, ami feltételezhetően szintén egy ősi termékenység isten, Uras nevéből gyökeredzik, valamint a „Ninurta utasításaiként” dedikált ún. „Farmer Almanac” dokumentum, amely egy mezőgazdasági használati utasítás. Az óbabiloni időszakban a nippuri E-sumesa templomba tehető kultuszának centruma, majd később Lagasba, ám ezekben a városokban még „Enlil fia Ninurtaként” tisztelték őt (Leick, 2003). Az óbabiloni időszak végére Ninurta népszerűsége megcsappant Marduk javára, viszont az első évezred fordulójára hadi szerepköre felértékelődött és népszerűvé vált az asszír uralkodók és a katonai réteg tagjai között (Penglase, 2005). Noha a következőkben vizsgált mítoszok közül Marduk személyében több királyi princípiumra történő utalással és szimbólummal találkozunk, Ninurta legalább olyan fontos szerepet töltött be az uralkodói patronálásban.

2.sz. kép: Pecséthenger Kr.e. 10-8. század, nem egyértelmű jelenet. Marduk és Tiamat vagy Ninurta és a basmu kígyó küzdelme

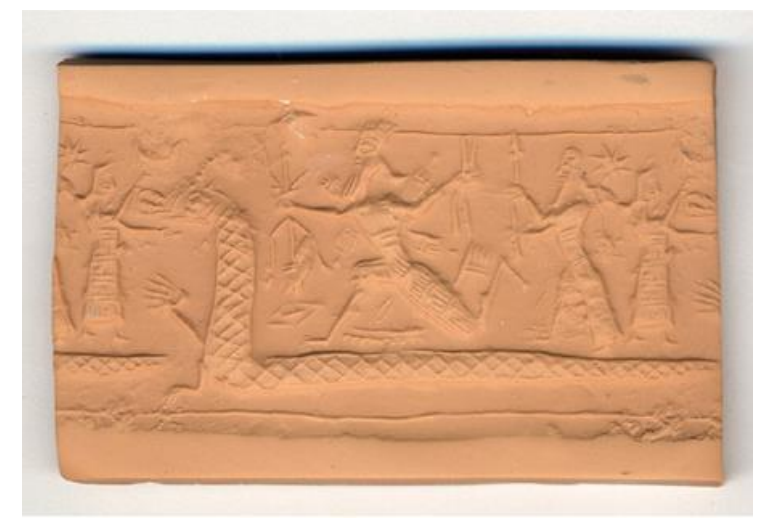

Forrás: British Museum online katalógus, Museum ID: 89589

Ninurta uralkodók közti jelentősége leginkább Asszíriában volt kimagasló, ahol II. Assur-nászir-apli (Kr.e. 883-859) királyfelirata alapján a 9. században még Ninurta adta rituálisan tovább az uralkodóknak a hatalmat szimbolizáló jogart. (Annus, 2002) A két isten egymáshoz mért jelentőségét tehát nem az alá-fölé rendeltség határozza meg, mivel mindketten fontos szerepet töltöttek be a saját kultuszkörzetükben. Talán ez is közrejátszhatott karaktereik találkozásában.

\section{A forrásokról}

A szövegek keletkezésének körülményeiről csak megközelítőleges információink állnak rendelkezésre. Mítoszok esetében régészeti leletekből csak a történetek adott hordozóinak korát keltezhetjük, további leletek híján nem zárhatjuk ki egyiknél sem a tartalom korábbi verzióit, ahogy azt sem mondhatjuk biztosan, hogy ezek a történetek lennének az első, eredeti változatok. 
Az Enuma elis Tiamat és Marduk epikus harcát elmesélő babiloni teremtéseposz, bár Lambert szerint a világ teremtésének szála, Marduk főistenné válásának csak járulékos következménye és nem a történet fókusza. Ea isten, Apsu (édesvíz) és Tiamat (sósvíz) nászából születő harmadik istengeneráció leszármazottja megtudja, hogy őseik meg akarnak tőlük szabadulni, így megöli apjukat. Apsu meggyilkolása után Tiamat haragra gerjed és szörnysereget toboroz maga köré, hogy elpusztítsa az isteneket. Ea és Anu isten kudarca után Mardukra száll szembe Tiamattal, aki így elnyeri a „minden isten feletti király" (sumer: Lugal-dimmer-ankia) címet és a legyőzött Tiamat darabjaiból megteremti a lakott világot és az embereket. Tettével a mítoszban fontos ünnepnapot, az Akitut jelöli ki, amely során Babilonban minden újév alkalmával ceremoniálisan felolvassák a történetet. A mítosz keltezésére még mindig nem született pontos becslés, valószínűleg a 13. század körül keletkezhetett (Bottéro, 1992), ami összeköthető az I. Nabú-kudurriuszur uralkodása alatti intézkedésekkel, Mardukot Babilon város főistenévé emelésével. A mítosz elsődleges célja is valószínúleg ennek a főisteni posztnak az alátámasztása és Marduk pozíciójának hivatalossá tétele lehetett (Lambert, 1992).

Az Anzu mítosz esetében két változatot különböztünk meg. A későbbi, standard babiloni Anzu mítoszt egy ún. óbabiloni verzió előzte meg, amelyben Ninurta helyett Ningirsu isten állt a történet középpontjában és az antagonista Anzu madár szerepe is eltérő volt a későbbi változattól. A számunkra fontos standard babiloni Anzu mítosz tábláit asszír territóriumon tárták fel Ninive, Tarbisu és Sultantepe területéről, a szöveg eddig legelfogadottabb keltezése a 10. század és a 7. század közé tehető (Dalley, 2008). A standard babiloni verzióban Anzu, az oroszlán-sas hibrid madár elrabolja Enlil istentől a Végzet Táblákat („Tablets of Destiny”), amivel veszélybe sodorja a világrend egyensúlyát. A táblák visszaszerzésére három isten visszautasítása után Ninurtát nevezik ki. Az isten felkészítést kap az anyaistentől Belet-ilitől és apjától Enliltől. A szelek természetfeletti irányításával Enki (akkád: Ea) isten tanácsával legyőzi Anzut, visszaszerzi az isteneknek a táblákat és visszaállítja a rendet. Az istenek cserébe hatalommal, nevekkel és titulusokkal ruházzák őt fel és bosszúállójuknak nevezik őt ki. Bertman szerint a mítosz értelmezhető aszerint is, hogy egy felső hatalmi rendet mennyire tud sakkba szorítani egy individuum fenyegetése és a bekövetkező árulásnak elkerülhetetlen következményei vannak. Emiatt a történet figyelemfelkeltésként is szolgálhatott a potenciális politikai tégláknak (Bertman, 2003).

Az összehasonlításból megszülető konklúziót óvatosan, minden végbemenő következtetéstől mentesen kell meghoznunk annak a veszélynek a figyelembevételével, hogy a két isten mítoszbeli különbségeit ne egymás alá-fölé rendeltségeként azonosítsuk, mivel mindketten különböző városok panteonjaiban foglalnak el magas pozíciót és állnak szoros összeköttetésben az uralkodói réteggel. 
3.sz. kép: Relief, Kr.e. 9. század Nimrud (Kalhu), Ninurta templom. Ninurta küzdelme Anzu madárral

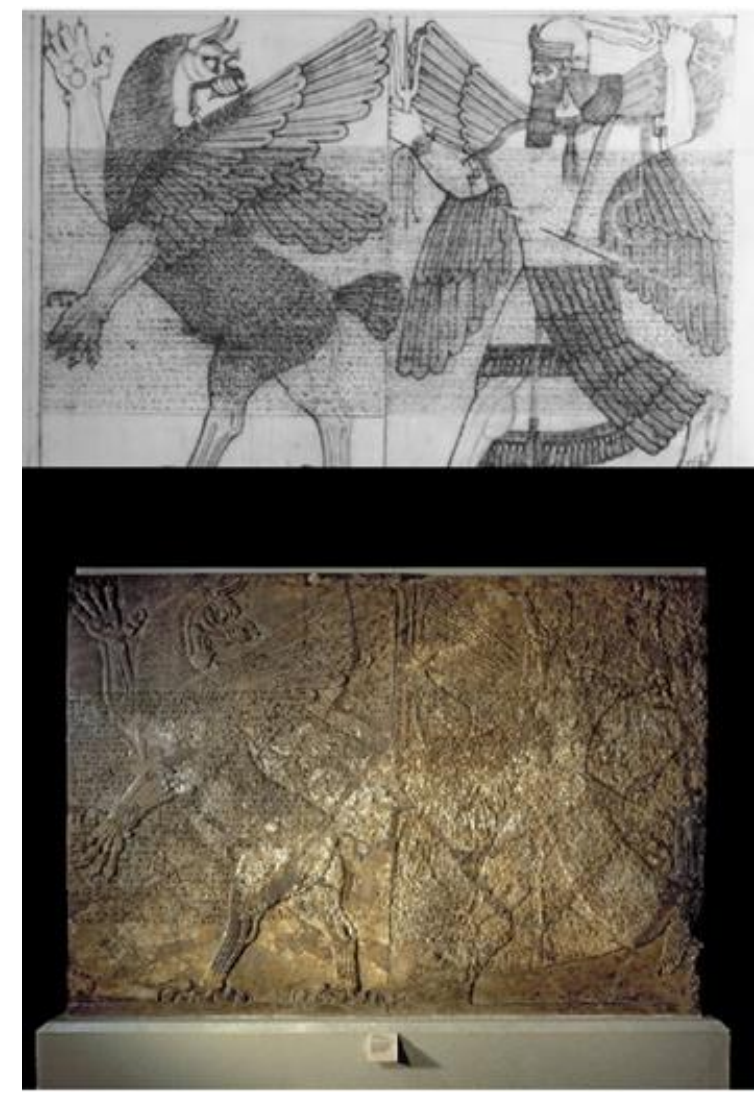

Forrás: British Museum online katalógus, Museum ID: 124571

\section{Összehasonlítás}

Körülmények. A mítosz cselekményét, fordulatait, főszereplőit és konfliktusait befolyásoló tényezők.

Az Anzu és az Enuma elis körülményeinek hasonlósága a világot fenyegető káoszban találkozik, abban azonban nem mutat teljes egyezést. Mindkét esetben az istenek által fenntartott rend kerül veszélybe, amely védelmének feladata egy harcosra hárul, azonban ennek a „rendnek” a történetek szerinti definíciójában fedezhetünk fel különbséget. Noha míg az Anzuban is találkozunk a bosszúállás fogalmával, a műben a világrend felborulását kiváltó, bizonyos nagy hatalmú táblák elrablásáról olvashatunk. Az Enuma elis cselekményét tekintve közelebb áll egy bosszútörténethez, ha az antagonista Tiamat motivációit vesszük figyelembe: Ea isten miután tudomást szerzett a szülők gyermekeik ellen konspirált tervéről, meggyilkolja apjukat Apsut, amivel okot ad Tiamatnak csemetéik elleni tervük beteljesítésére. Az istenek által fenntartott rend nem táblákban ölt alakot (noha előfordul a történetben), Tiamat az összes isten létét, így az addig alkotott világot fenyegeti. Ezzel szemben az Anzuban sokkal egyszerűbb körülményekkel állunk szemben. Wisnom azzal érvel, hogy a két szöveg központi konfliktusának súlyozása között különbséget lehet tenni a fordulatok mélységének vizsgálatával. Marduk 
felsőbbrendűségének és győzelmének determináltsága már a csata kezdete előtt megmutatkozik: Az istenek nem kérnek meg mást, a fiatal isten önként vállalkozik a feladatra, habár először őt is kételkedés fogadja nagyapja Anshar részéről. ${ }^{i}$

Az Anzu mítoszban Ninurtát három másik isten: Adad, Gerra és Shara felkeresése előzi meg, akik visszautasítják az Anzuval való küzdelmet, végül Ea ötletére találnak a harcosra, a feladatot viszont az istenek anyja, Belet-ili nyújtja át neki. A megkeresést visszautasító három másik isten és Ninurta szerepkörében érdekes kontrasztot találhatunk: Adadot (sumer: Ishkur) viharistenként tisztelték már a korai dinasztiák óta (Black, et al., 2004.), Gerra (sumer: Gibil) túzisten, Shara, Ishtar fia a sumer Umma város patrónus istene. (Dalley, 2008) Háromból kettejük szoros összeköttetésben áll a természeti erők irányításával és mindhárman korai sumer istenek. ii

\section{Motiváció. A hős tettét mozgató belső és külső hajtóerők}

A motiváció szorosan összefügg az előbb tárgyalt körülményekkel, amennyiben mindkét istennél a káosz erőinek legyőzése iránti szándékot feltételezzük. Az istenek feladatra való kiválasztása vagy önként jelentkezése tovább árnyalja a motivációkat, a különbséget ebben találjuk. Az Enuma elisben Marduk önként jelentkezését követően tettének követelményeit saját maga szabja ki. Ez a lépése automatikusan az addigi legfőbb pozíciókat betöltő istenek fölé emeli őt.iii

A fentebb idézetek többször visszatérő sorok a mítoszban. Marduk saját mindenhatóságát nevezi meg Tiamat legyőzésének és a többi isten megmentésének feltételeként. Ninurta esetében a megkeresés a megbízók felől automatikusan a jutalmak megnevezésével is jár, úgy, ahogy az az őt megelőző három másik istennél is. Ez a szövegrészlet egy visszatérő elem, amellyel az Anzuban két formában találkozhatunk: A felkérés elfogadása előtti és utáni verzióval. Az előbbi sorok csak egyszer fordulnak elő, a felkérést követő dicsérő szavak többször.iv

Az Anzuban elhangzó visszatérő narrációs elemek az isten megnevezését és kultuszhelyeinek felállítását ígérik. A hangsúly a kultuszon van, amelyet Ninurta tettével legitimál az istenek között. Ebből következtetve feltételezhetjük, hogy a megkeresést megelőzően az elhangzó ígéretek ellentéte jellemezte az istenek között Ninurtát, tehát nem rendelkezett kiemelkedő jelentőséggel a panteonban, ahhoz szükséges az Anzu feletti győzelem. A két isten fentebb vizsgált motivációi közti különbség a jutalmak mértéke és azok szolgáltatói között keresendő. Marduk önkéntes vállalkozása révén saját maga szabja ki a feltételeket, amely maga a mindenhatóság. Ezzel ellentétben Ninurtát egy ajánlattal keresik meg, „fix jutalmakkal”, amelyeket az őt megelőző három istennek is felajánlottak. Ninurta elfogadja az ajánlatot így a feladat teljesítését követően érvényt nyer kultuszának az istenek között. Ninurta a mítoszból csak annak a három istennek a személyén emelkedik felül, akik visszautasították az ajánlatot, míg Marduk minden isten fölé helyezi magát. Ha elfogadjuk, hogy a két történetet azonos sémára írták, úgy a későbbi verzióban felhasználhatták elődje történetének a vázát és tudatosan pozícionálták a főszereplő istent a fentebb kifejtett jutalmazási és motivációs rendszerrel. 


\section{Konfliktus. A jelenet, amelyben az isten az antagonistával konfrontálódik}

Terjedelmüket tekintve az Enuma elis összesen hét táblára, míg az Anzu standard babiloni verziója jóval rövidebb, három táblára írt mítosz. A művek hosszának ellenére az Anzuban jóval bővebb kifejtést kap a küzdelmi jelenet, mint az Enuma elisben, így aránytalanság, vagy inkább fordított arányosság mutatkozik a két mű harcjelenetének hosszában. Míg az utóbbiban a teljes küzdelem nagyjából hetven sorban olvasható, Ninurta több jelenetes, fordulatokkal és teátrális kiszólásokkal ékelt harcát olvashatjuk. Mi lehet a különbség és hasonlóság a két isten gonosszal vívott csatája között?

Marduk és Tiamat a IV. tábla 92. sorában találkoznak és 162. sorában oltja ki Marduk Tiamat életét. A két pont között a konfrontáció az alábbi jelenettípusokra osztható fel:

1. rész: Dialógus (IV. 92-147): A felek találkoznak, Marduk elmondja Tiamat bűneit és konfliktust kiváltó okokat és szemtől szembeni küzdelemre szólítja őt fel.

2. rész: Harcjelenet (IV. 148-162): Marduk a szelek feletti uralmát kihasználva megbénítja Tiamatot és nyílvesszőt lő a száján keresztül a szívébe. ${ }^{v}$

Az Anzuban Ninurta és Anzu a II. tábla 46. sorában találkoznak és a III. tábla 28. sorában adja át a főhős az isteneknek a táblákat. A két pont között a konfrontáció az alábbi jelenettípusokra osztható fel:

1. rész: Dialógus (II. 46-62): A felek egymás iránti szándékaikat ismertetik.

2. rész: Környezeti leírás (II. 63-80): Az ütközetnek helyet adó hegyi környezet kozmikus leírása az előzőleg felkeresett istenek részvételével.

3. rész: Harcjelenet (II. 81- III. 26)

3.1. Anzu felhasználja a táblák természetfeletti erejét Ninurta ellen. (II. 81-97)

3.2. Ninurta elküldi Sharur nevű fegyverét Ea istenhez tanácsért. (II. 98-226)

3.3. Ninurta végez Anzuval. (III. 1-28)

A harcjelenet leghosszabb részét Sharur hírközlése teszi ki, amely a mítoszban egy ismétlődő szövegrészlet. Két információt kétszer olvashatunk (Ninurta tanácskérését és Ea tanácsát), végül Ninurta kegyetlenül végez Anzuval: a szelek irányításával megbénítja és megöli a teremtményt.vi

A két harcjelenet között egyaránt találhatunk hasonlóságot, de több különbséget. A hősök sikere ellenfelükkel szemben már a mítosz kezdetén biztosított volt, csak a győzelmük felé vezető út közelíti meg máshonnan a végkimenetelt. Marduknál és Ninurtánál a szelek feletti kontroll, majd megbénult ellenfelük szívének fegyverrel történő átszúrása számolható fel hasonlóságnak mindkét isten esetében. De ahogy láthatjuk, Ninurta sokkal brutálisabb módon végez Anzuval: a szívén kívül a tüdejét is átszúrja, a szárnyait átlövi egy nyílvesszővel és találhatunk utalást a szövegben a szárnyak letépésére is. Mindezt Ea isten tanácsára teszi, miután ellenfele sakkba szorította őt a birtokában lévő táblák használatával, úgy, hogy a kilőtt nyílvessző alkotóelemeit visszaküldte azok eredeti, természetben elfoglalt helyére. Ninurtával szemben Mardukot nem éri semmilyen meglepetés Tiamat felől. Az isten utasítja ellenfelét a szemtől szembeni küzdelemre, amelyben gyorsan és tisztán végez vele. Az Enuma elis teljes hosszából és küzdelmi jelenetének felépítéséből láthatjuk: a hangsúly nem a harcon van, Marduk győzelme még az egyenlőtlen erőviszonyok, valamint a Tiamat mögött felsorakozó szörnysereg ellenére is biztos, ezt viszont nem szabad betudnunk Ninurta 
alsóbbrendűségének. Fontos megjegyezni, hogy a Tiamat hadseregében említett szörnyek közül számos teremtménnyel Ninurta is szintén megküzd más mítoszokban, így például a basmu kígyóval vagy a kusarriku bölényemberrel (Haas, 2019). Ninurta az Anzu mítoszon kívül több mítoszban utazik szörnyekre vadászni, ahonnan a szörnyek trófeáival díszített harci szekerén tér vissza (Angim mítosz), tehát Tiamat és Ninurta azonos tevékenységet végeznek: Ezek a szörnyek a civilizált életteren kívül, a nem-megszentelt és belakott kozmoszban foglalnak helyet, ezért a szörnyeknek ez a fajta meghódítása és leigázása a városokon kívül eső tér meghódítása, biztonságossá tétele, és a város mint rendezett világ allegóriájának védelme (Annus, 2002). Az istenek ezen tevékenysége a háborúba indult uralkodó felé támasztott elvárásokkal mutat egyezést, aki seregével profán térben felszámolja a káosz erőit megtestesítő ismeretlen ellenséget és győzelmével helyre állítja a békét.

\section{Eszközök. A főszereplő istenek által használt, vagy a cselekményt befolyásoló eszköztár}

A mítoszokban előforduló eszközöket fizikai és természetfeletti kategóriákba sorolva vizsgálhatjuk. Az istenek szempontjából Marduk és Ninurta a küzdelemhez elengedhetetlen kellékei a személyes fegyverarzenál és a különböző égtáji szelek, amelyek fölött teljes kontrollt gyakorolnak. Az istenek eszközein kívül mindkét mítoszban találkozunk bizonyos „Végzet Tábláival” (Dalley: Tablets of Destinies), amelyek jelentősége más hangsúlyt kap az Enuma Elisben mint az Anzuban. Míg az utóbbi mítoszban a drámai alaphelyzet ezeknek az isteneknek a számára fontos értéket képviselő és a leírás alapján a teljes hatalmat biztosító tárgyak Anzu általi elrablása köré épül, az Enuma elisben is hatalmi jelentőséggel bír, ez viszont nem befolyásolja Marduk felkészültségét. Az Anzuban a táblák a leginkább a sumer mitológiából ismert ún. „me” khez hasonlíthatóak, amelyek az élet területei fölötti teljes princípiumot biztosító isteni hatalmak. (Szexualitás, papság, rituális feladatok elvégzése, öreg kor, csend stb.) Ezek nem sebezhetetlenek, eltűnésüket vagy megrongálódásukat a világban zajló katasztrófákkal magyarázzák (Leick, 2003). Az Enuma elisben megjelenő táblákat Tiamat egyik szolgájának, Qingunak adja át még a harc előtt, amivel egyaránt átruházza rá az „Anu-erőt" is. vii

Ez az átruházott erő az első nemzett istengeneráció hatalmával lehet egyenlő, Marduk felülemelkedése Qingun azt mutathatja, hogy ő már egy másik generáció istene, akire nem hatnak a régi világ szabályai. Ezek a táblák az Anzuban sakkban tartják Ninurtát és a főhős hatalmukat csak Ea isten segítségével képes megkerülni.

Az istenek fegyverei, amelyekkel harcba indulnak nagyon hasonló Marduk és Ninurta esetében is: (A táblázat néhány elemét fordítási pontatlanság elkerülése miatt angolul használom.) 
1. sz. táblázat: Fegyverek a vizsgált mítoszokban

\begin{tabular}{|l|c|c|}
\hline & Marduk (Enuma elis) & Ninurta (Anzu) \\
\hline \hline Íj és nyíl & $\mathrm{x}$ & $\mathrm{x}$ \\
\hline Dárda & $\mathrm{x}$ & $\mathrm{x}$ (Sharur) \\
\hline Buzogány/zúzófegyver & $\mathrm{x}$ & $\mathrm{x}$ \\
\hline Háló & $\mathrm{x}$ & $\mathrm{x}$ \\
\hline „Throw stick” & $\mathrm{x}$ & $\mathrm{x}$ \\
\hline Szelek & $\mathrm{x}$ & \\
\hline Villám & $\mathrm{x}$ & \\
\hline „Flood-weapon” & & \\
\hline Harci szekér & & \\
\hline
\end{tabular}

Forrás: Dalley, 2008

A fenti táblázatban az istenek fegyverzetét láthatjuk. A „throw-stick” kivételével Marduk jóval nagyobb felszereléssel rendelkezik, mint Ninurta, azonban a Sharur nevű buzogány az isten több mítoszban is visszatérő személyes fegyvere. Sharur egy bizonyos intelligens zúzófegyver szerepét tölti be, ami fizikai formájából adódó funkcióján kívül egyéb természetfeletti képességgel ruházza fel használóját, például az Anzuban a Ninurta és Ea közötti információ közvetítés. Sharur esetében a fegyver zúzó/buzogány típusa csak feltételezés, pontosabb megfejtés erre még nem született. Sharur valószínűleg egy alacsonyabb rendű isten fegyverbe öntött megszemélyesítése lehet (Dalley, 2008). A buzogány mindkét isten fontos eszköze, nem csak harci, hanem hatalmi, fallikus szerepet is betölthet úgy, ahogy a villámok és a szelek feletti uralom is lehet hatalmi szimbólum. Marduk a buzogányát használja Tiamat fejének a betörésére a csata után. Szintén ilyen hatalmi jelvényként jelenik meg Marduknál a harci szekér használata is, amely a 2 . évezred második felétől már csatadöntő fegyvernemnek számított. A háló használata határeset az istenek és emberek eszköztárában, a fogóháló használata vadászat esetén volt inkább gyakoribb, harc során nem tudjuk, hogy használták volna. Marduk hálóval bénítja meg Tiamatot, majd szintén hálóval fogja össze az ellenfelét kísérő szörnysereget is (Pálfi, 2010). A viharok, szelek és természeti erők használatából mindkét istennél egyfajta időjárási attribútumra következtethetünk; az ún. „flood-weapon”, amely mindkettőjüknél előfordul, természeti erőt, valószínűleg vizet szimbolizáló fegyver lehet.

\section{Jutalom. A hős tettéért cserébe kapott jutalom}

A két isten tettéért járó ellensúlyozás szoros összefüggésben áll a motivációval, de a kritérium a vizsgálat előtt pontosabb magyarázatra szorul. Az alábbi sorokban a mítoszok végén olvasható hőst érintő változás kerül bemutatásra, amely vagy a hős személyét vagy Marduk esetében például az őt körülvevő világot érinti. Mindkét mítosz esetében a feladat elvégzésével a hősök egyfajta megkülönböztetett előnyös helyzetbe kerülnek, ami közös 
nevezőként mindkettőjük esetében a világ megmentése, valamint a méltóságok és nevek felvétele. Marduknál ez egy összetett és hosszú részlete a szövegnek. Tiamat halálával először megteremti a világot ellenfele testrészeiből, ezután megtörténik a váltás az isten rangjában, és a Lugaé-dimmer-ankia címmel ruházzák fel (Királya Minden Égi És Földi Istennek, Dalley, 2008).viii

Marduk ezután megalapítja házát, kultuszának centrumát ahová az Apsuból és az égből gyűlésre érkező istenek megszállhatnak, és ezt a helyet Babilonnak nevezi el. Az isten teljesen elölről kezdi a világ teremtését és felosztását, mindezt a többi isten jelenlétében, akik a háború kirobbantóját Qingut hozzák elé, hogy Marduk az ő véréből teremtsen embereket. Az istenek esküt tesznek neki és címekkel ruházzák őt fel: Mardukot összesen ötven névvel illetik, amelyek az istenek között betöltött kiemelkedő pozícióját, rendkívüli képességeit, méltóságát és tiszteletét hangsúlyozzák. Az elhangzó nevek közül a Bel (Úr) gyakori utalás Mardukra (Black, et al., 2004).

Ninurta győzelmét követő jutalmazása a névadásban, illetve az isten panteonban betöltött kultuszának legitimációjában nyilvánul meg. Egy Birdu nevű isten konferálásában olvashatjuk Ninurta tizenhét méltóságát, amelyeket az írásért felelős Nissaba isten rögzít. Marduk és Ninurta felsorolt nevei között nincs átfedés, a nevekhez rövid definíció társul, Ninurtánál csak egy felsorolást olvashatunk. Az Enuma elistől eltérően, amely egy mindenható uralkodói pozíció felvételét írja le, az Anzu végén egy olyan beavatás ismerhető fel, amely során az isten kultusza kiemelt helyre, de mégsem mindenható szintre kerül. ix

\section{Konklúzió}

Fontos leszögeznünk, hogy a fenti vizsgálattal a két isten kultuszában felépített karaktereinek csak egy szeletét tanulmányoztuk. A kapott eredmény két olyan isten személyét tárta elénk, akik mindketten egy saját panteonon belüli váltáson mennek keresztül és viselkedéseik, tetteik és karaktereik átfedésben állnak egymással. Azonban ahogy azt fentebb említettem, ezt a váltást nem szabad kizárólag a mítoszokhoz kötnünk, ugyanis nem zárható ki, hogy már a történetek előtt is éltek ezek az elképzelések. Az Enuma elis és Anzu alapvető különbsége ennek a váltásnak a mértékében keresendő: Nehéz vállalkozás meghatározni, hogy Marduk főisteni pozícióját a létrejövő babiloni ideológia generálta, vagy fordítva történt, minden esetre a Marduk kultusz fontos eleme volt ennek a városközpontú eszmének. Marduk és Ninurta mindkét mítoszban a saját környezetük hierarchiájának csúcsán foglal helyet. A kiválasztottság és a civilizált rend káosztól való védelme, a legyőzhetetlen szörnnyel, mint ismeretlennel való szembeszállás és az isteni rend győzelemre vezetése hősi karakterjegyek, amelyek a kor uralkodói erényeivel mutatnak egyezést. Jordan B. Peterson az archetipális mítoszelmélet kortárs kutatója szerint pszichológiai (nem teológiai) megközelítésben a Marduk-képzet a „szentdominancia-hierarchia" csúcsára csak sok évszázados mitológiai desztilláció során juthatott fel, amely során a törzsi mítoszok isteneinek kompetenciái egyesültek végül egy tökéletes, világot teremtő és irányító tudó isten elképzelésében, aki Marduk lett (Peterson, 2015). Ezek az attribútumok könnyen adaptálható uralkodói értékek, amelyek 
az éppen regnáló uralkodónak azonosulási pontként szolgálhattak. A mítoszok vizsgálati eredményei alapján a két istenről alkotott vallási elképzelés szintén nagyon hasonló lehetett. (Legalábbis ott, ahol egyszerre tisztelték őket.) Amíg hivatalos városi patrónusként töltöttek be funkciót, valószínűleg összeköttetésben állhattak az uralkodóról alkotott elképzeléssel is, amely többek között a legyőzhetetlen szörny, mint az ellenség felett aratott győzelem és a rend, mint béke visszaállításának képzetéből is meríthetett. Ez összeköttetésben állhat azzal is, hogy az istenek erős maszkulin tulajdonságokkal rendelkeznek: zúzófegyverek mint fallikus szimbólumok virtuóz használata, az izmos testfelépítés és erőnlét a férfias tulajdonságok közé sorolhatók. A tanulmány végső konklúziójaként kijelenthetjük, hogy Marduk és Ninurta személyisége a vizsgált mítoszokban az uralkodói hős-idea elképzelésében találkozik, és a tudattalan tartalmat szimbolizáló szörny megölésével egy magasabb, transzcendens létezési szintre juttatja ezt az ideát (Jung, 2003).

A Marduk és Ninurta között feltételezett szinkretizmus vizsgálatát további mítoszok-, vallási irodalmi források, illetve ikonográfiai ábrázolások bevonásával lehetne tovább bővíteni. Ezen vizsgálatok eredményei között az istenekről alkotott képzetekről, a mezopotámiai hős-idea fogalmi absztrakciójáról, illetve istenekhez fűződő szellemi élményről kaphatunk tisztább képet, amelyek ezeknek a történeteknek az olvasása/hallgatása közben foganhattak meg az egyénben.

\section{Irodalomjegyzék}

Abusch, T. (1999). Marduk. In van der Toorn, A., Becking, B., \& van der Horst, P.W. (Eds.), Dictionary of Deities and Demons in the Bible (DDD) (543-549). Cambridge: Brill.

Annus, A. (2002). The God Ninurta in the Mythology and the Royal Ideology of Ancient Mesopotamia. State Archives of Assyria Studies 14. Helsinki: Neo-Assyrian Text Corpus Projectof the University of Helsinki \& Finnish Oriental Society.

Assmann, J. (1996). Translating Gods: Religion as a factor of cultural (un)translatability. In Budick, S. \& Iser, W. (Eds.), The Translatability of culture: figurations of the space between (25-36). Stanford: Stanford University Press.

Bertman, S. (2003). Handbook to Life in Ancient Mesopotamia. New York: University of Windsor.

Black J. \& Green, A. (2004). Gods, Demons and Symbols of Ancient Mesopotamia. London: The British Museum Press.

Bottéro, J. (1992). Mesopotamia - Writing, Reasoning, and the Gods. Chicago \& London: The University of Chicago Press.

Dalley, S. (2008). Myths from Mesopotamia - Creation, The Flood, Gilgamesh, and Others, New York: Oxford University Press.

George, A. R. (1997). Marduk and the cult of the gods of Nippur at Babylon. Orientalia NOVA SERIES, 1997 (66), 65-70.

Haas, V. (2019). Mágia és mitológia Babilónban - Démonok, boszorkányok és ráolvasások. Budapest: L'Harmattan.

Handy, L. K. (1992). Marduk. In Freedman, D.N. (ed), The Anchor Bible Dictionary (vol. IV.) (722-723). New York: Doubleday.

Jung, C. G. (2003). Bevezetés a tudattalan pszichológiájába. Budapest: Európa.

Jung, C. G. (2011). A kollektív tudattalan archetípusairól. Budapest: Scolar Kiadó.

Lambert, W. G. (1992).: Enuma elish. In Freedman, D. N. (ed), The Anchor Bible Dictionary (Vol. II.) (722726), New York: Doubleday.

Leick, G. (2003). A Dictionary of Ancient Near Eastern Mythology. New York: Routledge. 
Pálfi, Z. (2010). Marduk és Tiámat küzdelme, avagy az istenek fegyverzete. Ókor: folyóirat az antik kultúráról, 9. (1), 11-18.

Penglase, C. (2005). Greek myths and Mesopotamia. New York: Routledge.

Peterson, J. B. (2015). 2015 Maps of Meaning 05b: Mythology: Enuma Elish/Part 2. (Jordan Peterson), 2015.

február 6. YouTube

https://www.youtube.com/watch?v=VJVMtUb-LEY

Rákos, S. (1974). Gilgames/Agyagtáblák üzenete. Budapest: Európa Könyvkiadó.

Tokarev, Sz. A. (1988).: Archetípusok. In Mitológiai Enciklopédia (Vol. I.). Budapest: Gondolat Kiadó.

Wisnom, S. (2019). Blood on the Wind and the Tablet of Destinies: Intertextuality in Anzû, Enūma eliš, and Erra and Išum. Journal of the American Oriental Society, 139. (2) 269-286.

Képek forrása:

1. kép, British Museum, London

https://www.britishmuseum.org/collection/object/W_1920-1211-435

Letöltés dátuma: 2020.10. 20.

2. kép, British Museum, London

https://www.britishmuseum.org/collection/object/W_1896-0619-1

Letöltés dátuma: 2020. 10. 20.

3. kép, British Museum, London

https://www.britishmuseum.org/collection/object/W_1851-0902-502

Letöltés dátuma: 2020.10.20.

Az elemzéshez használt fordítások:

i „(Anshar:) What kind of man has ordered you out (to) his

war?

My son, (don't you realize that) it is Tiamat, of

womankind, who will advance against you with

arms?

(Marduk:) Father, my creator, rejoice and be glad!

You shall soon set your foot upon the neck of Tiamat.,

(Dalley, 2008: Enuma elis II., 190-197)

Magyar fordítás:

„(Anshar:) Férfi-é vajjon, aki harcba hívott?

Asszony csupán - Tiámat - a dühöngő!

(Marduk:) Örvendezzél, vígadj, mivelhogy

hamarosan nyakára léphetsz" (Rákos, 1974: Teremtés II., 114-119)

„Then Marduk, sage of the gods, your son, came

forward.

He wanted of his own free will to confront

Tiamat." (Dalley, 2008: Enuma elis III., 85-88)

Magyar fordítás:

„ám jő Marduk, a Bölcsek Bölcse 
s Tiámat ellen menni nem fél , (Rákos, 1974: Teremtés III., 60-61)

ii „Adad answered the speech,

Addressed his words to Anu his father,

'Father, who could rush off to the inaccessible mountain?

Which of the gods your sons will be Anzu's conqueror?"

(Dalley, 2008: Anzu I., 120-125)

Magyar fordítás:

„Így válaszol atyja szavára, nemzője beszédére ekként felel mennydörgő Adad isten: „mint hághatnék a hághatatlan hegyekre én, Zút hogy lebírjam; mint vághatnék a vághatatlan sűrűbe én, Zút hogy megöljem?"

(Rákos, 1974: Az isteni viharmadár... , 51-57)

„They called Belet-ili, sister of gods, to him, Wise counsellor of the gods her brothers."

(Dalley, 2008: Anzu I., 225-226)

Magyar fordítás nem elérhető

„(Then) Ea told the idea in the depths of his inmost being.

...

Offer the powerful one, your superb beloved, Broad of chest, who forms the battle array!

Give Ninurta, your superb beloved, Broad of chest, who forms the battle array!" (Dalley, 2008: Anzu I., 229-237)

Magyar fordítás nem elérhető.

iii „If I am to defeat Tiamat and save your lives,

Convene the council, name a special fate,

Sit joyfully together in Ubshu-ukinnaku:

My own utterance shall fix fate instead of you!

Whatever I create shall never be altered!

The decree of my lips shall never be revoked, never changed!"

(Dalley, 2008: Enuma elis II., 210-216) 
Magyar fordítás:

„Istenek atyja, sorsok rendelője!

Megbosszúlom rettegéseidet,

legyőzöm Tiámatot; ám előbb

hívd össze az istenek valahányát;

Ubsukinna szent dombján gyúljön egybe

az isten-nyáj s fogadjon pásztorául;

szavam szavad helyett megálljon,

a sorsok intézője légyen;

mindegyik istennél leghatalmasabb

legyen a nevem és másíthatatlan

amit teremtek s hegyként magasodjék

minden időkben ajakam parancsa!"

(Rákos, 1974: Teremtés II., 123-136)

iv "[Then shall his name be] Lord in the great gods'

assembly.

Let him show prowess to [the gods, that his name

may be Powerful].

[Let his name be made great in all populated

lands"

(Dalley, 2008: Anzu I., 238-243)

Magyar fordítás nem elérhető.

„Then shall kingship enter Ekur again,

Then shall rites return for the father who begot

you!

Then surely shrines be created!

Establish your cult centres all over the four

quarters!

Your cult centres shall enter Ekur!

Show your prowess to the gods and your name shall be

Powerful!"

(Dalley, 2008: Anzu II., 28-36)

Magyar fordítás nem elérhető.

${ }^{v}$ "To her face he dispatched the imhullu-wind, which

had been behind:

Tiamat opened her mouth to swallow it,

And he forced in the imhullu-wind so that she could not close her lips.

Fierce winds distended her belly;

Her insides were contstipated and she stretched her

mouth wide.

He shot an arrow which pierced her belly,

Split her down the middle and slit her heart,

Vanquished her and extenguished her life."

(Dalley, 2008: Enuma elis IV.,148-162) 
Magyar fordítás:

„ám az Úr vetett hálójába Tiámat vakul belelépett

s ijedtében nagyra-tátotta száját;

akkor Marduk küldé a szeleket, Tiámat szájrésébe valamennyit, hogy, bár akarta, sem csukhatta többé össze szétnyílott ajakát;

a szelek megtöltötték bensejét,

szíve elakadt, hab hörgött ki torkán;

az Úr pedig tollas nyílvesszejét a Ragyogó mellébe lőtte,

majd pallosát reávivé, derékban egy csapással kettészakasztván.

Meggyőzvén őt, eloltván éltetét,

sarka alá gyürt tetemét taposta."

(Rákos, 1974: Teremtés IV., 98-107)

vi „But as he shouted 'Wing to wing' a shaft came

up (?) at him,

A dart passed through his very heart.

He (Ninurta) made an arrow pass through pinion

and wing,

A dart passed through heart and lungs.

He slew the mountains, inundated their proud

pastures"

(Dalley, 2008: Anzu III., 8-23)

Magyar fordítás nem elérhető.

vii „She gave him the Tablets of Destinies, and made

him clasp it to his breast.

„your utterance shall never be altered! His

(! Your) word shall be law!"

When Qingu was promoted and had received the

Anu-power

And had decreed destinies for the gods her sons,

(he said)

„What issues forth from your mouths shall

quench Fire!

Your accumulated venom (?) shall paralyse her

powerful."

(Dalley, 2008: Enuma elis III., 71-82)

Magyar fordítás:

„Átaladta néki a sorstáblákat, mellére erősítvén szíjjal őket.

'Parancsod légyen megváltoztathatatlan, kijelentésed kőszálként

megálljon!'

Így lőn Kingu választott: anusága

isten-sorsokat kötni-oldani emelé Tiámat elsőszülöttjét.

Szólott az istenekhez: 'Szavatok

nyugtassa meg a nyugtalan tüzet!' 
Azok pedig hozsánnázva feleltek:

'Dicsőség néked! Harcban fenséges légy!

Reszkessen a dalmahodó Erőszak!"

(Rákos, 1974: Teremtés III., 49-58)

viii „Made their voices heard and spoke to the Igigi,

'previously Marduk was (just) our beloved son

But now he is your king. Take heed of his

command'

Next they spoke and proclaimed in unison,

'Lugal-dimmer-ankia' is his name. Trust in

him!"

(Dalley, 2008: Enuma elis V., 140-146)

(Lahmu and Lahamu)

Magyar fordítás nem elérhető.

ix „Ninurta, because you were so brave and slew the mountain,

You made all foes kneel at the feet of Ellil your

father.

You have won complete dominion, every single

rite."

(Dalley, 2008: Anzu III., 86-91)

Magyar fordítás nem elérhető. 